\title{
SC.C R.72-3154
}

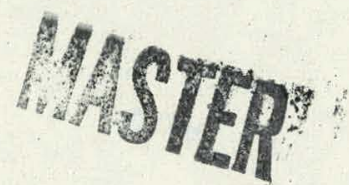

\section{Effects of Substituents on the Rates of Disproportionation of \\ Substituted Phenylglyoxals in Alkaline Solution ${ }^{1 a, b}$}

David L. VanderJagt, ${ }^{*} 1 \mathrm{C}$ Liang-Po B。 Han and Charles H. Lehman

Departments of Biochemistry and Chemistry,

University of New Mexico, Albuquerque, N.M. 87106

\section{NOTICE}

This report was prepared as an account of work sponsored by the United States Government. Neither the United States nor the United States Atomic Energy Commission, nor any of their employees, nor any of their contractors, subcontractors, or their employees, makes any warranty, express or implied, or assumes any

legal liability or responsibility for the accuracy, com-

pleteness or usefulness of any information, apparatus, product or process disclosed, or represents that its use would not infringe privately owned rights. 


\section{DISCLAIMER}

This report was prepared as an account of work sponsored by an agency of the United States Government. Neither the United States Government nor any agency Thereof, nor any of their employees, makes any warranty, express or implied, or assumes any legal liability or responsibility for the accuracy, completeness, or usefulness of any information, apparatus, product, or process disclosed, or represents that its use would not infringe privately owned rights. Reference herein to any specific commercial product, process, or service by trade name, trademark, manufacturer, or otherwise does not necessarily constitute or imply its endorsement, recommendation, or favoring by the United States Government or any agency thereof. The views and opinions of authors expressed herein do not necessarily state or reflect those of the United States Government or any agency thereof. 


\section{DISCLAIMER}

Portions of this document may be illegible in electronic image products. Images are produced from the best available original document. 
Abstract

A series of meta or para substituted phenylglyoxals, including $\mathrm{H}, \mathrm{p}-\mathrm{CH}_{3}, \mathrm{p}-\mathrm{OCH}_{3}, \mathrm{p}-\mathrm{Br}, \mathrm{p}-\mathrm{Cl}, \mathrm{p}-\mathrm{pheny} 1, \mathrm{~m}-\mathrm{OCH}_{3}, \mathrm{p}-\mathrm{NO}_{2}$ and $\mathrm{p}-\mathrm{OH}$, were examined for Linear Free Energy Relationships between chemical reactivity and substituent constants, and between chemical reactivity and carbonyl stretching frequencies of the ketone and aldehyde carbonyls. At pH 12, the hydroxide ion catalyzed disproportionation of the phenylglyoxals into the corresponding mandelic acids follows the Hammett relationship with $\rho=2.0$, indicative of a transition state stabilized by electron withdrawing groups. These rates of disproportionation also correlate quite well with the carbonyl stretching frequencies of the ketone carbonyls, both for the hydrated and the anhydrous phenylglyoxals. The aldehyde carbonyl stretching frequencies are essentially independent of ring substituents, $\nu_{c=0}=1727 \mathrm{t}_{2} \mathrm{~cm}^{-1}$. The disproportionation of $\alpha$-ketoaldehydes is known to involve intramolecular hydride migration. The results of the present study suggest that hydride migration is the rate determining step in the disproportionation of this series of substituted phenylglyoxals. 
Introduction

The glyoxalase system is composed of two enzymes, glyoxalase-I which utilizes glutathione (GSH) as coenzyme and catalyzes the disproportionation of methylglyoxal into the thiol ester of lactic acid and GSH, and glyoxalase-II which hydrolyzes this thiol. ester to regenerate GSH and liberate lactic acid. ${ }^{2,3}$ Scheme 1 sumarizes the reactions of the glyoxalase system. Reactions 1 and 2 of Scheme 1 are pre-enzymic reactions to form a hemimercaptal which is the actual enzyme substrate 4,5 . The net reaction in the glyoxalase system is the conversion of an $\alpha$-ketoaldehyde into an $\alpha$-hydroxycarboxylic acid. This is analogous to an intramolecular Cannizzaro reaction involving hydride migration from the aldehydic group to the $\alpha$-carbon. The glyoxalase-I reaction (reaction 3 of Scheme 1 ) is known to occur without solvent exchange of the aldehydic hydrogen 6,7 , as in the Cannizzaro reaction. The importance of the glyoxalase system is not yet clear. It is ubiquitous in nature, and there have been suggestions that the system may play an important role in the regulation of cell growth ${ }^{8}$. The general ability of methylglyoxal and other $\alpha$-ketoaldehydes to inhibit the growth of both bacteria and mammalian cells is well established 9,10 and has resulted in the specific suggestion that the glyoxalase system may. function in a regulatory capacity by monitoring intracellular methylglyoxal (or other $\alpha$-ketoaldehydes) concentrations. 11

The disproportionation of $\alpha$-ketoaldehydes in alkaline solution is . also an intramolecular Cannizzaro reaction. This reaction has been studied extensively, especially for phenylglyoxal $12,13,14$, and also involves migration of the aldehydic hydrogen without exchange with solvent ${ }^{13}$. Furthermore, Hine and Koser ${ }^{14}$ have established that the disproportionation of phenylglyoxal involves intramolccular hydride migration as the rate determining step. A summary of their purposed reaction sequence is given in Scheme 2. Comparison 
of the two reaction Schemes shows the formal similarity between the enzyme catalyzed reaction (3) and the hydroxide catalyzed reactions ( 7 and 8 ).

We have examined the effects of substituents on the hydroxide catalyzed disproportionation of a series of substituted phenylglyoxals in: order to 1). test whether reactions 7 and 8 involve rate determining hydride migration for a broad series of meta or para substituents; 2) examine this reaction for Linear Free Energy Relationships between reactivity and substituent constants; 3) attempt to explain the observed reactivity by analyzing the carbonyl stretching frequencies of the aldehyde and ketone carbonyls; 4) and obtain an understanding of reactions 7 and 8 as models for the glyoxalase-I reaction (3). We recently observed that the glyoxalase-I catalyzed disproportionation of substituted phenylglyoxals is insensitive to ring substituents ${ }^{15}$. This raises the question of whether reaction 3 involves rate determining hydride migration or whether hydride migration simply shows a very small substituent effect. Reactions 7 and 8 thus become critical models for reaction 3 . 
Scheme 1

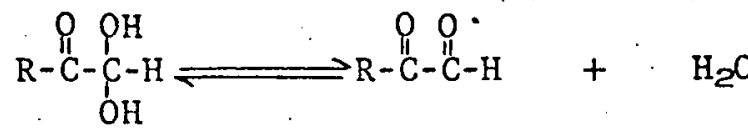

1

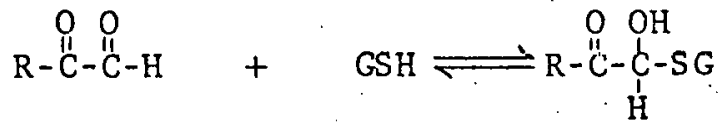

2

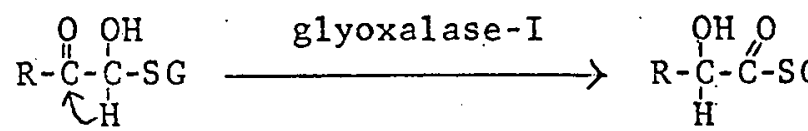

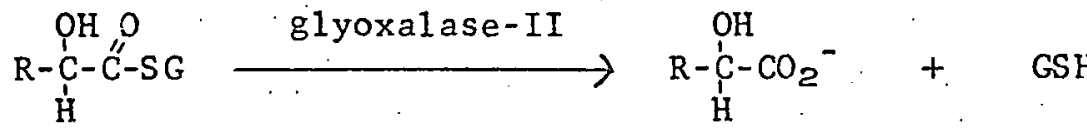

$$
\text { GSH }=\gamma-L-g 1 \text { utamy1-L-cysteinylglycine }
$$

Scheme 2

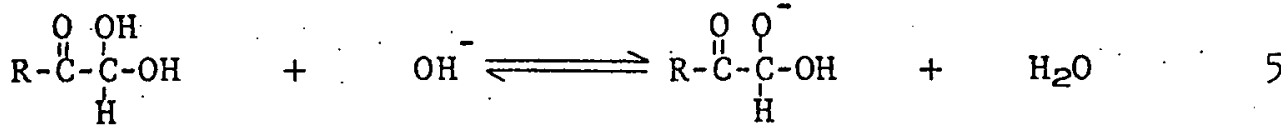

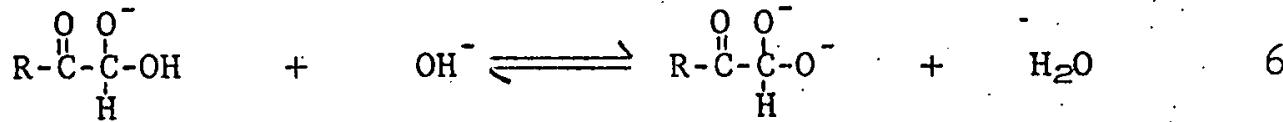

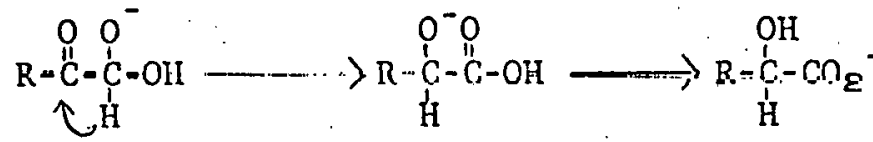

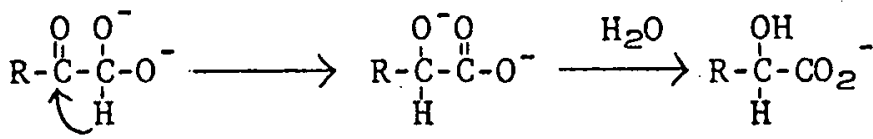


Results and Discussion

The rates of disproportionation of a series of substituted phenylglyoxal hydrates, including $\mathrm{H}, \mathrm{p}-\mathrm{CH}_{3}, \mathrm{p}-\mathrm{OCH}_{3}, \mathrm{p}-\mathrm{Br}, \mathrm{p}-\mathrm{Cl}, \mathrm{p}-\mathrm{phenyl}$, $\underline{\mathrm{m}}-\mathrm{OCH}_{3}$ and $\mathrm{p}-\mathrm{NO}_{2}$ were measured at $\mathrm{pH} 12$ by following the changes in the u.v. absorbances at the $\lambda_{\mathrm{MAX}}$ of the hydrates. Para-hydroxyphenylglyoxal was also examined. This member of the series disproportionated slowly at $\mathrm{pH} 12$ and, consequently, was reacted at higher $\mathrm{pH}$. The $\mathrm{p}-\mathrm{OCH}_{3}$ derivative was also disproportionated at this higher $\mathrm{pH}$ (ca. $0.1 \mathrm{M} \mathrm{NaOH}$ solution) and the factor $\mathrm{k}_{\mathrm{p}-\mathrm{OCH}_{3}}=39$ was assumed valid at $\mathrm{pH}$ 12. The $\mathrm{p}-\mathrm{OH}$ derivative $\mathrm{k}_{\mathrm{P}-\mathrm{O}^{-}}$

exists as the $\mathrm{p}^{-\mathrm{O}^{-}}$anion at high $\mathrm{pH}$. The pseudo first order rate constants obtained and the wavelengths employed are listed in TABLE I. There is a 3600 fold range in rate constants between the $\mathrm{p}^{-\mathrm{NO}_{2}}$ and $\mathrm{p}^{-\mathrm{O}^{-}}$derivatives, indicative of transition state stabilization by electron withdrawing groups. Figure 1 shows a Hammett plot of $\log \mathrm{k}$ vs. $\sigma_{\mathrm{x}}{ }^{16}$. for this series of compounds. A fairly good Linear Free Energy Relationship is observed. The slope, $\rho$, is 2.0, comparable in size and magnitude to the $\mathrm{OH}^{-}$catalyzed hydrolysis of substituted methylbenzoates ${ }^{17}$. The linear relationship over this wide range of substituents suggests a common mechanism for this series of disproportionations. In their study on the mechanism of disproportionation of phenylglyoxal hydrate, Hine and Koser $^{14}$ reported that the rate determining step is. the intramolecular hydride migration (reaction 7 or 8 of scheme 2) and that reaction 8 predominates at hydroxide concentrations above $3 \mathrm{mM}$. At $\mathrm{pH} 12$, both the mono- and dianion should contribute to the observed rate with the majority of reaction occurring via the dianion. The existence of a linear relationship for the entire series of substituted phenylglyoxals examined in 
the present study, at $\mathrm{pH} \mathrm{12,} \mathrm{appears} \mathrm{surprising,} \mathrm{if} \mathrm{both} \mathrm{reactions} 7$ and. 8 are involved. However, if the acidities of the hydrates (1.e., reactions 5 and 6 of Scheme 2) are insensitive to ring substituents, then the contributions of reactions 7 and 8 , respectively, would be insensitive to substituents, and a linear relationship might be anticipated. To examine this question, the carbonyl stretching frequencies of the subst1tuted phenylglyoxals were determined for the ketones in the hydrated compounds and for both the aldehydes and the ketones in the unhydrated compounds. The values are listed in TABLE II. The aldehyde carbonyl stretching frequency is $1727 \pm 2 \mathrm{~cm}^{-1}$, totally Insensitive to ring substituents, while the ketone carbonyls are quite sensitive to ring substituents, both for the hydrates and the unhydrated phenylglyoxals. If one assumes that the carbonyl stretching frequency reflects sensitivity to nucleophilic addition, one might expect that the extent of hydration of the aldehyde In aqueous solution and the $\mathrm{pKa}$ values of the hydrates will be similar for this entire series of phenylglyoxals. This would help explain the 1inear relationship observed in the rates of disproportionation at $\mathrm{pH}$ 12. This conclusion that the chemistry at the aldehyde group is insensitive to substituents agrees with earlier observations that the rates of addition of glutathione to the aldehyde groups of substituted phenylglyoxals (reaction 2, Scheme 1 ) and the dissociation constants of the resulting hemimercaptals are insensitive to ring substituents 15 If hydride migration is rate determining, and if the ketone carbonyl stretching frequencies reflect the influence of the ring substituents, linear relationships might be expected in plots of $10 \mathrm{~g}$ $k$ vs。 $\gamma c=0^{\circ} \quad$ Figures 2 and 3 show plots of $\log k$ vs. the ketone carbonyl 
stretching frequencies of the hydrates and the unhydrated phenylglyoxals, respectively. Fairly good Linear Free Energy Relationships are observed In both cases. The sensitivity of the reaction is about one log unit of $k$ for a $\Delta \nu_{c=0}$ of $13 \mathrm{~cm}^{-1}$. These results agree with the general conciusion that the carbonyl stretching frequency can be a good indicator of chemical reactivity. Previous studies have shown that ketone carbonyl stretching frequencies can also be good models for predicting reactivities of ester solvolyses proceeding by carbonium ion intermediates 18,19 .

The usefulness of reactions 7 and 8 as models for the glyoxalase-I reaction (reaction 3 , scheme 1) is 1imited. The high sensitivity of the $\mathrm{OH}^{-}$ catalyzed disproportionation of substituted phenylglyoxals to substituents compared to the lack of sensitivity ${ }^{15}$ in the glyoxalase-r reaction suggests that hydride migration may not be the rate determining step in the enzyme reaction. 
Experimental

The substituted phenylglyoxals used in this study were synthesized by the following general procedures.

Procedure A: ${ }^{20}$ A substituted acetophenone as a 1-2 M solution in dioxane containing an equivalent amount of selenous acid was refluxed for 4 hours. The mixture was concentrated by rotary evaporation, and the residue was vacuum distilled. The resulting oil was added to hot water to form the crystalline substituted phenylglyoxal hydrate which was recrystallized from chloroform, acetone. Procedure $B:^{21}$ A slurry of a substituted phenacylbromide in acetonitrile was treated with a slight excess of $\mathrm{AgNO}_{3}$. The resulting mixture was stirred for 24-48 hours at room temperature, filtered, and the solvent removed by rotary evaporation. The residue (a phenacylnitrate) was dissolved in diethylether and washed with water. After drying over $\mathrm{MgSO}_{4}$, the solvent was removed, and the residue was added to dimethylsulfoxide containing about $1 / 2$ sodium acetate. The mixture was stirred at room temperature for 30 minutes and then was poured into ice-water saturated with $\mathrm{NaCl}$. The resulting mixture was extracted with diethyl ether, washed with water, dried over $\mathrm{MgSO}_{4}$ and then the solvent evaporated off. The resulting substituted phenylglyoxal hydrate was recrystal1ized as in procedure $A$.

The substituted phenylglyoxal hydrates prepared by either procedure were colorless solids except for the $\mathrm{p}-\mathrm{NO}_{2}$ derivative which did not form a crystalline hydrate. The melting points, however, were observed to be somewhat variable during the recrystallization procedures. This presumably is a reflection of the extent of hydration and has also been observed by others $^{14}$. All of the substituted phenylglyoxals were converted into the dioxime derivatives for elemental analysis. The data for characterization of 
the series of phenylglyoxals are given in TABLE III. Rates of Disproportionation: :Phosphate buffers, $\mathrm{pH} 12, \mu=0.6$, were prepared using distilled, deiontzed water and reazent grade chemicals. Reaction rates were monitored at the $\lambda_{\operatorname{MAX}}$ values of the substituted phenylglyoxals obtained from u.v. spectra recorded in $\mathrm{pH} 7$ phosphate buffer using a Cary 15 recording spectrophotometer. In all cases, the substituted pheny 1glyoxals have molar extinction coefficients ca. $10^{4} \mathrm{M}^{-1} \mathrm{~cm}^{-1}$ at the $\lambda_{\mathrm{MAX}}$ whereas the substituted mandelate products show low absorption at these wavelengths. The reaction rates were measured on a Gilford 222 recording spectrophotometer employing Beckman DU optics. The temperature was controlled with a circulating water bath. First order rate constants were obtained from computer calculated least squares slopes of plots of $10 \mathrm{~g}$ absorbance change vs. time. Correlation coefficients were generally better than 0.999 . Reactions were initiated by addition of small quantities $\left(10-20 \mu 1\right.$.) of $1: 1$ ethan $\mathrm{l}, \mathrm{H}_{2} \mathrm{O}$ stock solution of the substituted phenylglyoxals. These small quantities were placed on the end of a flattened stirring rod and introduced directly into the spectrophotometer cell containing $3.0 \mathrm{ml}$. of temperature equilibrated buffer. The ethanol was generally useful for preparing stock solutions of convenient concentrations. Use of stock solutions without ethanol gave the same rate data. The initial concentrations of substituted phenylglyoxals in the reaction cell were generally ca。 $10^{-4} \mathrm{M}$.

Carbonyl Stretching Frequencies: The ketone and aldehyde carbonyl stretching frequencies were measured on a Perkin-Elmer 621 recording spectrophotometer using very slow scan rates and expanded scales. General1y, the range 1800$1600 \mathrm{~cm}^{-1}$ was scanned over a one hour period, and a polystyrene standard was added to the cell holder immediately after the carbonyl band was passed in order to accurately locate the carbonyl stretching frequency. This procedure gave 
values reproducible to $\pm 1.5 \mathrm{~cm}^{-1}$.

The ketone carbonyl stretching frequencies of the substituted phenylglyoxal hydrates were measured in Nujol mul1s. The ketone and aldehyde carbonyl stretching frequencies of the unhydrated compounds were determined in dilute acetonitrile solutions. Although carbonyl frequencies are generally measured in carbon tetrachloride solutions, it was found that the unhydrated phenylglyoxals in carbon tetrachloride rapidly deteriorate, presumably by polymerization. Only a trace of water is required to initiate polymerization. Acetonitrile solutions were sufficiently stable to allow slow scanning rates to be used. The anhydrous solutions were prepared by warming acetonitrile solutions of the hydrates over molecular seives, with repeated transfers to fresh molecular seives. 
(1) (a) This work was supported by U.S. Public Health Service, National Cancer Institute (1RO1 CA 11850-01) and U.S. Atomic Energy Commission under Sandia Corporation Contract 51-1985. An equipment grant from Research Corporation is also gratefully acknowledged. (b). A preliminary report of this work was presented at the Southwest Regional Meeting of the American Chemical-Society, San Antonio, Dec., 1971. (c) Address correspondence to this author at the Department of Biochemistry, University of New Mexico School of Medicine, Albuquerque, N. M. 87106.

(2) E. Racker, J. Biol. Chem., 190, 685 (1951)

(3) Review article on glutathione and the glyoxalase system: W. E. Knox in "The Enzymes", P.D. Boyer, H. Lardy and K. Myrback, eds., Academic Press, New York, 1960, Vo1. 2, p. 253.

(4) E.E. Cliffe and S.G. Waley, Biochem. J., 79, 475 (1961)

(5). K.A. Davis and G. R. Williams, Can. J. Biochem., 47, 553 (1969) .

(6) V. Franzen, Chem. Ber. 89, 1020 (1956)

(7) I. A. Rose, Biochim. Biophy. Acta, 25, 214 (1957).

(8) A. Szent-Gyorgyi, Science 149, 34 (1965)

(9) L.G. Egyud and A. Szent-Gyorgyi, Proc. Natl. Acad. Sci., U.S., 55, 388 (1966).

(10) M. A. Apple and D.M. Greenberg, Cancer Chemother. Rep., 21, 455 (1967)

(11) A. Szent-Gyorgyi, L.G. Egyud and J.A. McLaughlin, Science, 155, 539 (1967)

(12) E. R. Alexander, J. Am. Chem. Soc, 9, 289 (1947)

(13) W.v.E. Doering, T.I. Taylor and E.F. Schoenewaldt, ibid., 70, 455 (1948)

(14) J. Hine and G.F. Koser, Jo Org. Chem., 36, 3591 -(1971)

(15) D.L. VanderJagt, L-P.B. Han and C.H. Lehman, Biochem., submitted for publication.

(16) Sigma values taken from J. Hine, "Physical Organic Chemistry", 2nd. ed.; McGraw-Hi11, Now York, 1962, p. 87.

(17) $H_{\circ}$ van Bekkum, P.E. Verkade and B.M. Wepster, Recl. Trav. Chim. Pays-Bas, 78, 815. (1959).

(18) C.S. Foote, J. Am. Chem. Soc., 86, 1853 (1964)

(19) P. von R. Schleyer, J. Am. Chem. Soc., 86, 1854 (1964) 
(20) H.A. Riley and A.R. Gray, Org. Syn., Coll. Vol. II, 509 (1943)

(21) N. Kornblum and H.W. Frazier, J. Am. Chem. Soc., 88, 865 (1966). 
TABLE I. Rate Constants for the Disproportionation of Substituted Phenylglyoxals; pH $12,25^{\circ}$. a

\begin{tabular}{|c|c|c|c|c|}
\hline $\mathrm{x}$ & $k\left(10^{-4} \sec ^{-1}\right)$ & $\log k$ & $\sigma x$ & $\lambda(n \mathrm{~m})^{d}$ \\
\hline $\mathrm{H}$ & $7.60 \pm 0.13$ & 0.881 & 0.0 & 251 \\
\hline $\mathrm{p}-\mathrm{CH}_{3}$ & $3.05 \pm 0.05$ & 0.484 & -0.170 & 263 \\
\hline $\mathrm{p}-\mathrm{OCH}_{3}$ & $1.37 \pm 0.04$ & 0.137 & -0.268 & 287 \\
\hline $\mathrm{p}-\mathrm{Br}$ & $13.9 \pm 0.1$ & 1.143 & +0.232 & 264 \\
\hline $\mathrm{p}-\mathrm{Cl}$ & $12.2 \pm 0.3$ & 1.086 & +0.227 & 260 \\
\hline $\mathrm{p}-\varnothing$ & $7.91 \pm 0.08$ & 0.898 & -0.01 & 292 \\
\hline $\mathrm{m}-\mathrm{OCH}_{3}$ & $10.1 \pm 0.1$ & 1.004 & +0.115 & 255 \\
\hline $\mathrm{p}-\mathrm{NO}_{2}$ & $125 \pm 5$ & 2.097 & +0.778 & 268 \\
\hline$p-0^{-}$ & $0.035^{\mathrm{b}}$ & -1.46 & -1.00 & 284 \\
\hline
\end{tabular}

a Rates measured spectrophotometrically in phosphate buffer, $\mu=0.6$.

b $\mathrm{p}-\mathrm{OH}$ phenylglyoxal exists as the $\mathrm{p}^{-0^{-}}$derivative at high $\mathrm{pH}$. Since this substituted phenylglyoxal is quite stable at $\mathrm{pH} 12$, it was disproportionated at higher $\mathrm{pH}$ along with the $\mathrm{p}-\mathrm{OCH}_{3}$ compound, and the factor $\mathrm{p}-\mathrm{OCH}_{3} .=39$ was assumed applicable at $\mathrm{pH} 12$. $\mathrm{p}-\mathrm{O}^{-}$

c Values for $\sigma_{\mathrm{x}}$ obtained from reference (16).

d $\lambda_{\text {MAX }}$ values of the substituted phenylglyoxal hydrates, $\mathrm{pH}$.7. The rates of disproportionation were monitored at these wavelengths. 
TABLE II Infrared Carbonyl Stretching Frequencies of the Ketone and Aldehyde Carbonyls of Substituted Phenylglyoxals and Their Hydrates.

\section{Substituent}

$$
\chi_{c=0}\left(\mathrm{~cm}^{-1}\right) \text {. }
$$

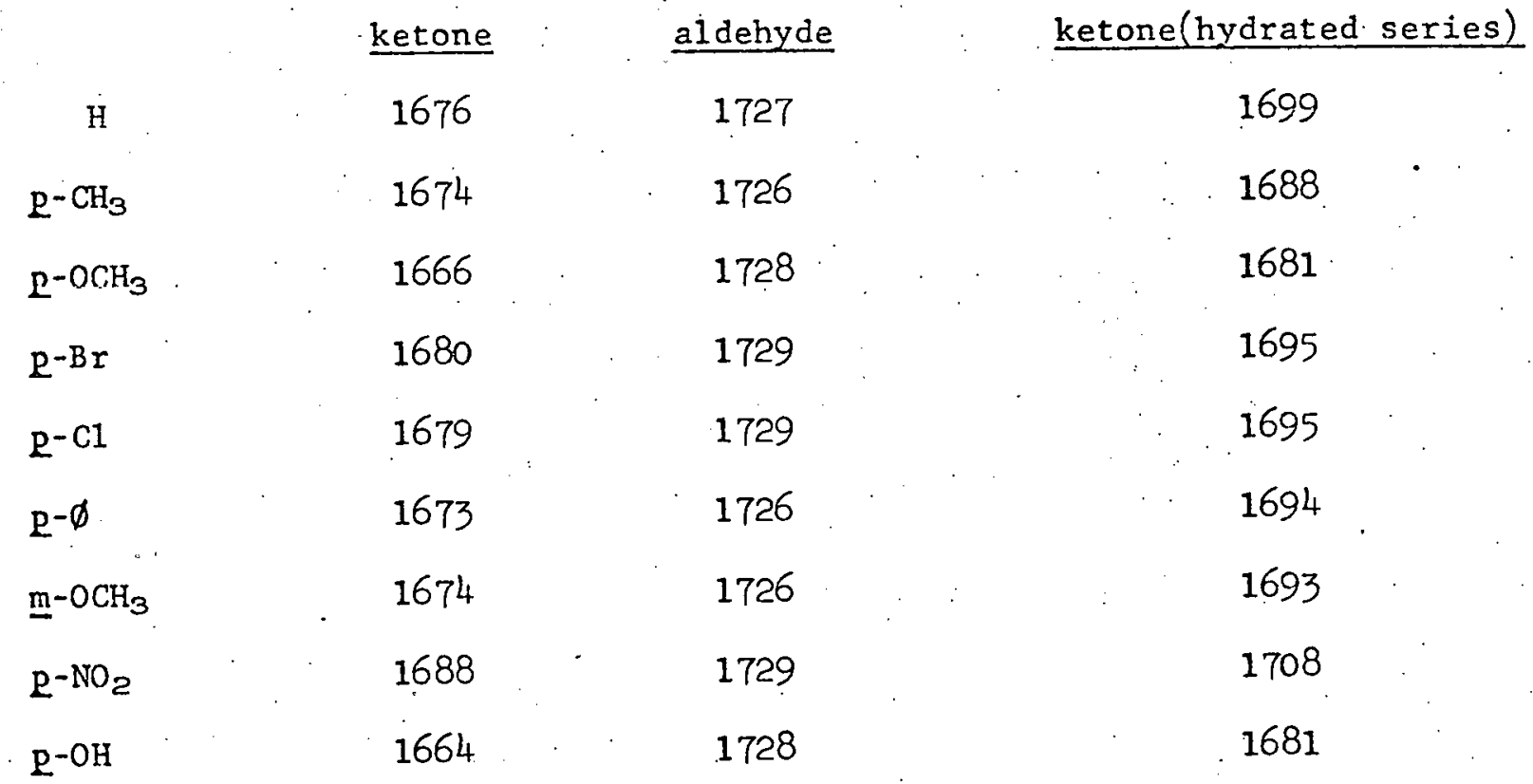


$\therefore$-TABLE-III "Characterization of Substituted - Phenylglyoxals

\section{substituent}

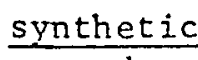

procedure

H

$\mathrm{p}-\mathrm{CH}_{3}$

A

$\mathrm{p}-\mathrm{OCH}_{3}$

B

A $\quad 76-77$

$\frac{\text { M. P. (hydrate) }}{{ }^{\circ} \mathrm{C}}$

M.P. (dioxime).

$\underline{E}$

C

H

N

$58.53 \quad 4.91 \quad 17.06$ calculated

$58.70 \quad 5.10 \quad 17.04$ observed

$$
\mathrm{p}-\mathrm{Br}
$$

B.

$\mathrm{p}-\mathrm{Cl}$

B

$\mathrm{p}-\varnothing$

$\underline{\mathrm{m}}-\mathrm{OCH}_{3}$

B

$\mathrm{P}-\mathrm{NO}_{2}$

A

$\mathrm{p}-\mathrm{OH}$

$$
98-99
$$

$126-127.5$

$174-176$

$166.5-168.2$

60.67

60.81

$5.66 \cdot 15.96$

$\begin{array}{ll}5.63 & 15.87\end{array}$

55.67

55.85

$5.19 \quad 14.43$

$152-153$

$133.5^{\circ}-134.9$

$167.5-168.5$

$120-122$

$159-160$

$116-118$

$216-.218$

$77-78.5$

$163.5-164.8$

39.53

39.74

2.90

3.14

.48 .38

$3.55 \quad 14.10$

48.28

$3.73 \quad 14.33$

69.99

70.02

$5.03 \quad 11.66$

$4.94 \quad 11.59$

55.67

.55 .73

$5.19 \quad 14.43$

45.94

45.92

$3.37 \quad 20.09$

$131-132 / 3 \operatorname{mm}$ a $\quad 186-188$

$190-193$
3.54 .20 .40

$4.48 \quad 15.55$

$4.73 \quad 15.86$
53.33

53.15

a Boiling point of $\mathrm{p}-\mathrm{NO}_{2}$ derivative. 


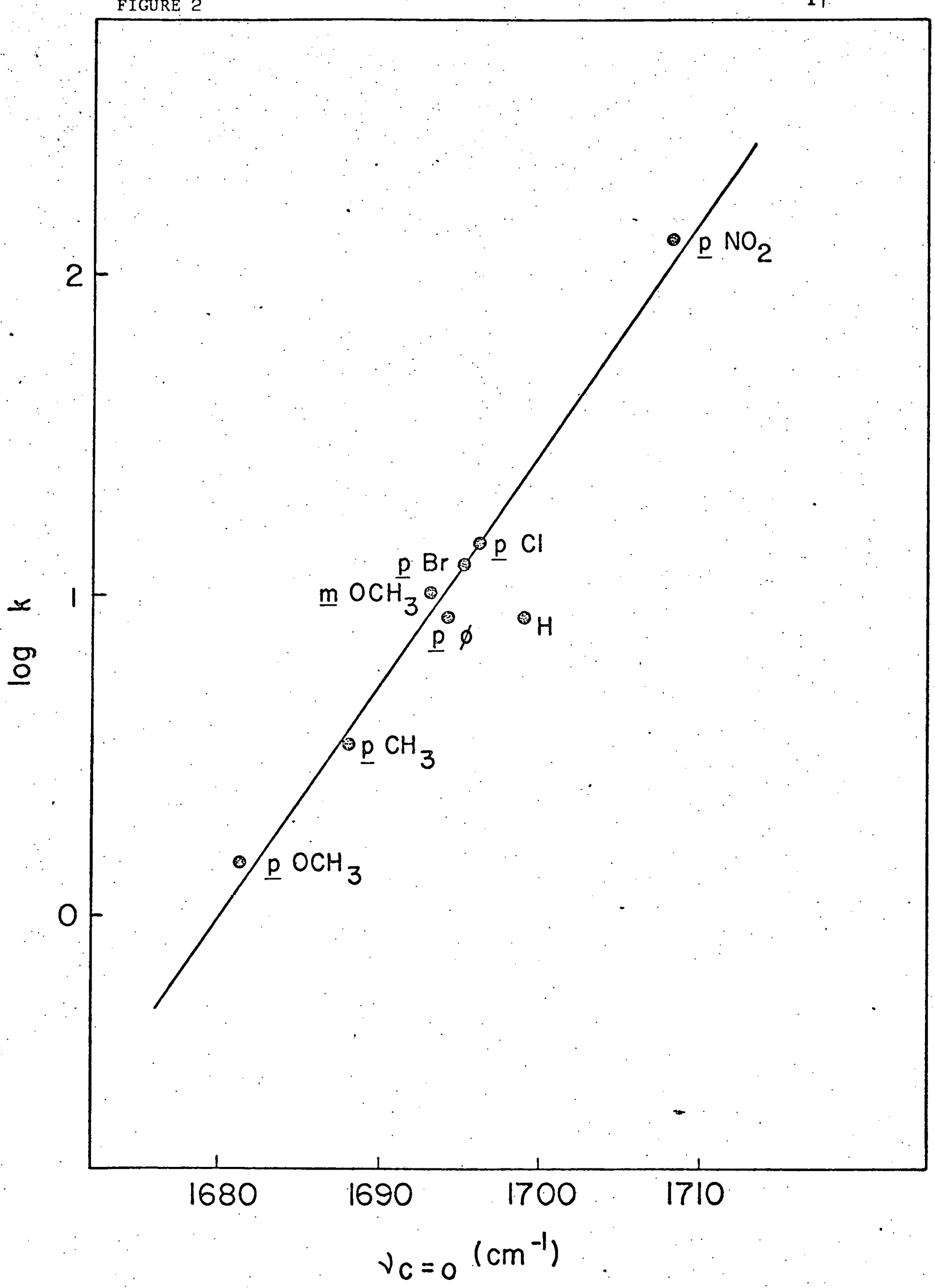




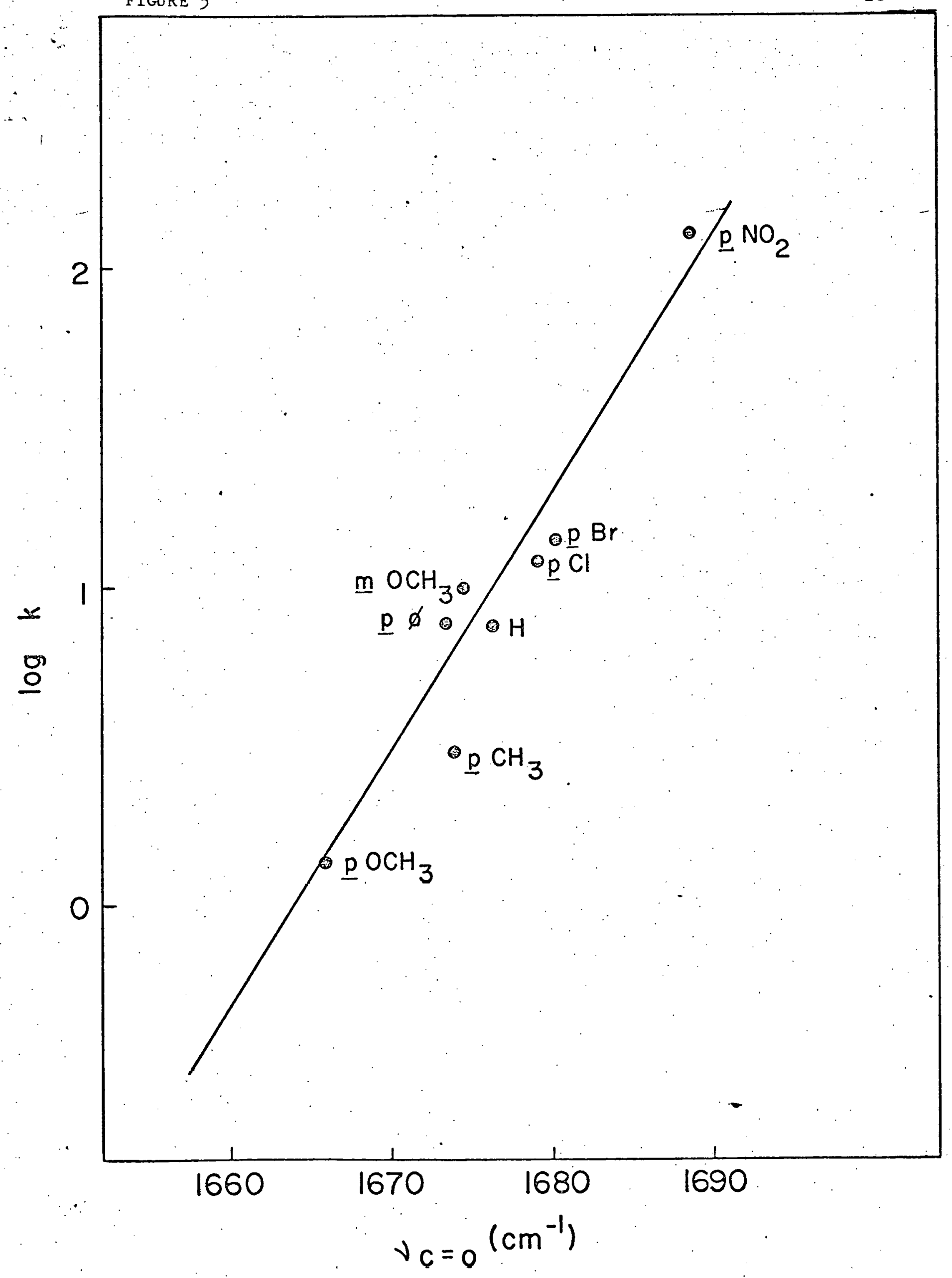


FIGURE LEGENDS

FIGURE 1 Hammett plot of $\log k$, the rate constants for the disproportionation of the substituted phenylglyoxals, $\mathrm{pH} 12$, vs. $\sigma_{\mathrm{x}}$. slope, $\rho$, is 2.0 .

FIGURE 2 Plot of $\log \mathrm{k}$, the rate constants for the disproportionation of the substituted phenylgiyoxals, $\mathrm{pH} 12$, vs. the ketone carbonyl stretching frequencies of the hydrated phenylgiyoxals.

FIGURE 3 Plot of $\log \mathrm{k}$, the rate constants for the disproportionation of the substituted fhenylglyoxals, $\mathrm{pH} 12$, vs. the ketone carbonyl stretching frequencies of the anhydrous phenylglyoxals. 